\title{
Alterations in the expression of certain midgut genes of Spodoptera littoralis (Boisd.) (Lepidoptera: Noctuidae) larvae and midgut histopathology in response to Bacillus thuringiensis Cry1C toxin
}

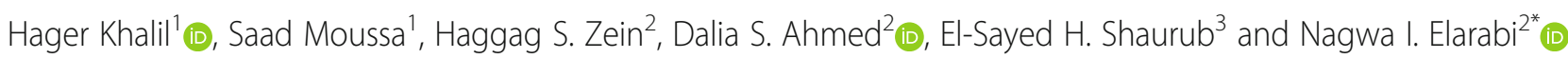

\begin{abstract}
Background: Bacillus thuringiensis $(B t)$ utilization as a biological control agent is highly recommended due to its safety, specificity, and efficiency. Importance of the entomocidal Cry proteins secreted by Bt is dramatically increased subsequent Cry genes transformation into a number of economic crops, rendering them protection against insect attack. In the last decade, insect resistance against transgenic Bt crops is gradually raised in several lepidopteran pests. A better understanding of the processing of Bt CrylC toxin in the larval midgut of the lepidopteran pest species, the cotton leaf worm, Spodoptera littoralis (Boisd.), is very important to characterize the main regulatory elements of $B t$ tolerance.
\end{abstract}

Results: The present study aimed to define factors that are involved in insect tolerance toward Bt Cry $1 C$ through evaluating the mRNA level of trypsin (Try), aminopeptidase N (APN), alkaline phosphatase (ALP), cadherin (Cad), and cytochrome P450 (CYP) in both susceptible and cry1C tolerant strains of S. littoralis. Total RNAs were extracted from susceptible and tolerant strains to construct cDNAs. Quantitative real-time polymerase chain reaction (qPCR) showed a significant upregulation of CYP gene in tolerant strain. In contrast, the levels of expression of Try, ALP, and Cad were significantly downregulated in tolerant strain. APN relative mRNA expression did not show significant differences between susceptible and tolerant strains. Histologically, the midgut of late third-instar larvae of tolerant population S. littoralis showed vacuolization of the epithelium and disruption of both the peritrophic membrane and the striated boarder compared to the susceptible strain.

Conclusions: Obtained data indicated a relationship between exposing to Bt Cry $1 \mathrm{C}$ toxin and alteration of CYP, Try, ALP, and Cad expression in midgut of $S$. littoralis. These results may be an evidence for the important roles of CYP, Try, ALP, and Cad in the resistance development and toxicity to Bt Cry $1 C$. The results are useful for further illustrating of Bt Cry $1 C$ processing and S. littoralis tolerance.

Keywords: Spodoptera littoralis, Bacillus thuringiensis, Bt Cry1C toxin, Tolerance, aPCR

\footnotetext{
* Correspondence: nagwa.abdulfattah@agr.cu.edu.eg

${ }^{2}$ Genetics Department, Faculty of Agriculture, Cairo University, Giza 12613,

Egypt

Full list of author information is available at the end of the article
}

(๑) The Author(s). 2021 Open Access This article is licensed under a Creative Commons Attribution 4.0 International License, which permits use, sharing, adaptation, distribution and reproduction in any medium or format, as long as you give appropriate credit to the original author(s) and the source, provide a link to the Creative Commons licence, and indicate if changes were made. The images or other third party material in this article are included in the article's Creative Commons licence, unless indicated otherwise in a credit line to the material. If material is not included in the article's Creative Commons licence and your intended use is not permitted by statutory regulation or exceeds the permitted use, you will need to obtain permission directly from the copyright holder. To view a copy of this licence, visit http://creativecommons.org/licenses/by/4.0/. 


\section{Background}

The Egyptian cotton leaf worm, Spodoptera littoralis (Boisd.) (Lepidoptera: Noctuidae), is a polyphagous pest in subtropical and tropical regions. The long-term applications of conventional pesticides to control pests, including S. littoralis, have led to the developments of resistance, negative impacts on the ecosystems, and unhealthy hazards to human and natural enemies. These problems are incentives to search for alternative safe and effective control measures with different modes of action. Biological control agents can be used where chemical pesticides are banned or where pests have developed resistance to standard chemicals and play an important role in integrated pest management (IPM) programs (Abdelhadi et al. 2016 and van Lenteren et al. 2018). Among these approaches is the use of the entomopathogenic bacterium, Bacillus thuringiensis $(B t)$ that provides a valuable alternative to chemical insecticides. (Dingha et al. 2004). Bt synthesizes delta-endotoxin protein crystals (Cry) that belong to a class of bacterial toxins are known as pore-forming toxins that specifically affect cell permeability and disrupting cellular integrity of insectmidgut cells. Cry toxins have a potent and specific insecticidal activity and can kill their insect larval hosts through a complex multi-step process resulting in the formation of a pore in the membrane of midgut epithelial cells (Soberón et al. 2018). Differences in the degree of solubilization possibly cause variability in the level of toxicity among Cry proteins. Solubilization is followed by proteolytic activation of the Cry protoxin by midgut digestive enzymes; the activated toxin crosses the peritrophic membrane, reaches the brush border membrane vesicles (BBMVs) of the midgut epithelium, and binds to the primary receptor cadherin in the microvilli (Pigott and Ellar 2007), which undergoes proteolytic cleavages that induce toxin oligomerization. After oligomers insertion, sequentially osmotic lysis of midgut epithelial cells occurs, followed by the creation of cytolytic pores in the membrane of midgut epithelial cells, septicemia, and ultimately insect death (Pardo-López et al. 2013).

Development of transgenic crops that express cry toxins was a remarkable breakthrough in pest control instead of the use of chemical insecticides (ISAAA 2017). The expression of certain Cry toxins in transgenic crops providing a more targeted and effective way to control insect pests in agriculture (James 2009). The expression of Cry protein in transgenic plants protects the insecticidal toxin from UV degradation and precisely targets chewing and boring insects. Nevertheless, the continuous expression of cry toxins in transgenic crops results in a gradual resistance development (Xiao and $\mathrm{Wu}$ 2019). Extensive studies have established that alteration of genes for toxins activation, and toxin-binding receptors confers high levels of $B t$ resistance in insects and subsequently threatens the sustained success of transgenic $B t$ crops (Fabrick et al. 2019). During attempts to unwind the complexity of $B t$ toxicity, other mechanisms associated with Cry toxins mode of action such as detoxication enzyme activities or innate immunity response were proposed (Boyer et al. 2012). Recently, alteration in CYP expression and activity due to exposure to cry toxins has been reported (Dhania et al. 2019). Thus, the correlation between CYP enzymatic activity and mechanism of $B t$ resistance is implied (Shabbir et al. 2019). A better understanding of the mode of action of $B t$ toxins and the mechanism of resistance at the molecular level is essential to improve strategies for monitoring and coping with the development of insect resistance, which assists in designing insect control strategies and extending the efficacy of $B t$ toxins as a control agent (Jin et al. 2018). Due to the existence of limited genetic information for $S$. littoralis, thus, the present study aimed to elucidate the molecular mechanism of $B t$ Cry $1 C$ tolerance, as a step to delay resistance development and guarantee a long-term efficacy of $B t$ in biological control.

\section{Methods}

\section{Insect culture}

Two strains of $S$. littoralis larvae were used in the present study: a susceptible strain and a Cry $1 C$-tolerant strain. A susceptible strain was provided by Insect Biotechnology and Molecular Biology Unit, Plant Protection Research Institute, Agricultural Research Center (ARC), Egypt, and fed on castor bean leaves, Ricinus communis, under the laboratory conditions $\left(25 \pm 1{ }^{\circ} \mathrm{C}, 70-80 \% \mathrm{RH}\right.$ and 14-h light:10-h dark photoperiod) for several years according to El-Defrawi et al. (1964). A Cry1C-tolerant strain was generated by selection pressure of a fieldstrain collected from Qalyubia Governorate, Egypt. Selection pressure was carried out by exposing newly hatched neonates to a semi-artificial diet (Rajagopal et al. 2009), mixed with partially purified $B t C r y 1 C$ toxin isolated from Bt entomocidus strain. Bt entomocidus strain was provided by Agricultural Genetic Engineering Research Institute, ARC, Egypt. The toxin dose increased gradually with the successive generations depending on the mortality percentage in each generation. Survived larvae were then shifted to castor bean leaves until pupation and adult emergence (Moussa et al. 2020). This process was repeated every generation to rise up Cry $1 \mathrm{C}$ tolerant strain. Ten generations were accomplished.

\section{Bt Cry1C toxin preparation}

The methods described by Moussa et al. (2016) were followed for $B t C r y 1 C$ toxin purification. Briefly, the bacterial cells were cultured for 3 to 5 days in T3 medium (per liter: $1.5 \mathrm{~g}$ yeast extract, $0.005 \mathrm{~g}$ of $\mathrm{MnCl}_{2}, 0.05 \mathrm{M}$ 
phosphate buffer $\mathrm{pH} 6.8,3.0 \mathrm{~g}$ tryptone, and $2.0 \mathrm{~g}$ tryptose) at $30^{\circ} \mathrm{C} / 150 \mathrm{rpm}$. The spores and crystals were harvested at $5500 \mathrm{rpm} / 10 \mathrm{~min}$ at $4{ }^{\circ} \mathrm{C}$ and then washed six times with $50 \mathrm{mM}$ EDTA at $9500 \mathrm{rpm} / 10 \mathrm{~min}$ at $4{ }^{\circ} \mathrm{C}$. The pellet was resuspended in $50 \mathrm{mM}$ Tris $\mathrm{HCl}, 5 \mathrm{mM}$ EDTA ( $\mathrm{pH} 7)$, and preserved in $-20^{\circ} \mathrm{C}$ until solubilization. Resuspension was centrifuged at 9500 $\mathrm{rpm} / 10 \mathrm{~min}$ at $4{ }^{\circ} \mathrm{C}$ and supernatant was removed. Two milliliters of solubilization buffer $\left(50 \mathrm{mM} \mathrm{Na} \mathrm{CO}_{3}, 10\right.$ mM DTT, pH 10.5) was added and incubated for $4 \mathrm{~h}$ at $37^{\circ} \mathrm{C} / 200 \mathrm{rpm}$, and then centrifuged at $14,000 \mathrm{rpm} / 30$ min at $4{ }^{\circ} \mathrm{C}$. Supernatant was aliquoted and kept at $-20{ }^{\circ} \mathrm{C}$ for further use. Toxin concentration was obtained by Bradford method (Bradford, 1976) and toxin integrity was checked on 10\% SDS PAGE.

\section{Bioassay}

Newly hatched neonates of a susceptible and a Cry1Ctolerant strains of $S$. littoralis were fed separately on a semi-artificial diet mixed with five concentrations of purified Bt Cry $1 C$ toxin: 0.2, 0.4, 0.8, 1.6, and $3.2 \mu \mathrm{g} / \mathrm{g}$ for susceptible strain and 2.0, 4.0, 8.0, 16.0, and $32.0 \mu \mathrm{g} /$ $\mathrm{g}$ for Cry1C-tolerant strain, following the techniques described by Rajagopal et al. (2009) and Moussa et al. (2016). Mortality percentage was recorded daily till the 7th day. Each concentration was replicated 3 times with 10 larvae each. A parallel control of 10 untreated larvae was also run. Each control was replicated 3 times. Treatments were conducted at different times, using different larval batches. Mortality percentage of each treatment was corrected using Abbott's formula (Abbott 1925). The $50 \%$ lethal concentration $\left(\mathrm{LC}_{50}\right)$ for each strain was estimated with the probit analysis. Resistance ratio (RR) was calculated as the $\mathrm{LC}_{50}$ for the tolerant strain divided by the $\mathrm{LC}_{50}$ for the susceptible strain.

\section{Histopathological studies}

Biopsy samples of the middle portion of the midgut of Cry1C-tolerant strain of S. littoralis late third-instar larvae were taken. Parallel controls of untreated susceptible strain larvae were also run. For light microscopy, the midgut was fixed in Bouin's solution. After dehydration in a graded ethanol series, the midgut was embedded in paraffin wax and cut $5 \mu$ thick using a rotary microtome. The sections were stained with hematoxylin and eosin and photographed with an Axiophot (Zeiss) light microscope according to Bancroft and Gamble (2008).

\section{RNA extraction}

The midguts of newly molted 3rd instar larvae of susceptible and $C r y 1 C$-tolerant strains of $S$. littoralis were dissected prior to RNA extraction. Triple biological replicates were conducted with five larval midguts each. Gene JET RNA Purification Kit (cat \# K0731) was used for total RNA extraction according to the manufacturer's instructions, and was quantified by absorbance at 260 $\mathrm{nm}$. One percentage agarose gel electrophoresis was utilized for RNA integrity determination. Extracted RNAs were treated with DNase I, RNase-free (cat \# EN0521), then reverse transcribed using an oligo $(\mathrm{dT})_{15}$ primer with GoScript ${ }^{\mathrm{TM}}$ Reverse Transcription System (cat \# A5000) as per manufacturer's instructions.

\section{Quantitative real-time polymerase chain reaction}

qPCR was conducted on the Stratagene Mx3005P QPCR System (Agilent Technologies Germany GmbH \& Co.KG, Waldbronn, Germany) using the SybrGreen method with Maxima SYBR Green qPCR Master Mix $(2 \times)$ (cat \# K0251). Primers were designed based on conserved regions of the targeted genes isolated from other lepidopteran insects and deposited in the GenBank database (Table 1). MultAlin (http://multalin.toulouse.inra.

Table 1 Genes name, sequence, and GenBank accession number

\begin{tabular}{|c|c|c|}
\hline Gene name & Species & $\overline{\text { Accession number }}$ \\
\hline \multirow[t]{3}{*}{ Try } & Spodoptera litura trypsin, alkaline C-like & XM_022965903.1 \\
\hline & S. litura trypsin-like serine protease & EF635223.1 \\
\hline & S. frugiperda trypsin & FJ940726.1 \\
\hline$A P N$ & S. littoralis aminopeptidase N (APN) & JF509138.1 \\
\hline \multirow[t]{3}{*}{$A L P$} & S. litura alkaline phosphatase 1 & JN687588.1 \\
\hline & S. litura alkaline phosphatase 2 & JN687589.1 \\
\hline & S. exigua alkaline phosphatase & KP420013.1 \\
\hline \multirow[t]{3}{*}{ Cad } & S. exigua cadherin-like protein & HQ647122.2 \\
\hline & S. exigua cadherin & HM116243.1 \\
\hline & S. exigua cadherin & KC907716.1 \\
\hline CYP & S. littoralis cytochrome CYP6AB14 & KX827419.1 \\
\hline 285 ribosomal RNA & S. littoralis 285 ribosomal RNA & KP682609.1 \\
\hline
\end{tabular}

Cad cadherin, ALP alkaline phosphatase, APN aminopeptidase N, Try trypsin, CYP cytochrome P450 
$\mathrm{fr} / \mathrm{multalin} /$ ) was used for nucleotide sequence alignment for each gene (Corpet 1988). Primers were designed using GenScript Primer Design tool and expected to amplify about $100-150 \mathrm{bp}$ fragment (Table 2). A $28 \mathrm{~S}$ rRNA gene served as a reference gene. The selected genes were amplified under the following conditions: $95^{\circ} \mathrm{C}$ for $10 \mathrm{~min}$, followed by forty cycles of $95^{\circ} \mathrm{C}$ for 30 s, $53^{\circ} \mathrm{C}$ for $60 \mathrm{~s}$, and $72^{\circ} \mathrm{C}$ for $30 \mathrm{~s}$. The melting curve analysis was utilized to analyze the specificity of the qPCR product. Relative expression fold changes were calculated by using formula $2^{-\Delta \Delta C T}$, which was proposed by Livak and Schmittgen (2001). The comparative $\mathrm{Ct}$ $(\Delta \Delta \mathrm{Ct})$ was measured by subtracting $\Delta \mathrm{Ct}$ of calibrator from $\Delta \mathrm{Ct}$ of treated samples.

\section{Statistical analysis}

EPA Probit analysis program (version 1.5) (kindly provided by Dr. Gujar G.T., New Delhi, India) was utilized to estimate the $50 \%$ lethal concentration $\left(\mathrm{LC}_{50}\right), 95 \%$ fiducial limits (FL), and the slope for results of the bioassay by probit analysis. The real-time polymerase chain reaction was done in three wells (replicates) for all genes. To determine the significance $(P \leq 0.05)$ among the mean differences of the groups, the independent unpaired Student's $t$ test was used the Statistical Package for the Social Sciences version 23 (SPSS, IBM, Armonk, NY, USA). All data were analyzed with a significance level of $5 \%$.

\section{Results}

Tolerance level of S. littoralis larvae to Bt Cry1C toxin

In this study, the field $S$. littoralis strain underwent selection pressure for 10 generations to rise up Cry1C-tolerant strain. Bt Cry $1 C$ toxin was partially purified and used for S. littoralis treatment. The SDSPAGE showed the presence of the Bt CrylC toxin at $\sim 135 \mathrm{kDa}$ protein (Fig. 1). After 10 generations, the tolerant strain showed $76.67 \%$ mortality rate at $32.0 \mu \mathrm{g}$ toxin per gram diet, while it was $70.00 \%$ at $3.2 \mu \mathrm{g} / \mathrm{g}$ in susceptible strain (Table 3). As a result of the subsequent selection pressure for 10 generations, the $\mathrm{LC}_{50}$ of the tolerant strain reached $12.263 \mu \mathrm{g} / \mathrm{gm}$

Table 2 PCR primer sequences

\begin{tabular}{|c|c|c|}
\hline Gene & Forward $\left(5^{\prime}-3\right)$ & Reverse $\left(5^{\prime}-3^{\prime}\right)$ \\
\hline$P$ & CGTAGAGC & GCTGT \\
\hline$P N$ & CCGGCTCCTACACCATTACT & GAGT \\
\hline$P$ & ACTGCGGAGACAG & AGT \\
\hline$y$ & TGGTGACA & GCGGGTAGCC \\
\hline ad & ACCAGCTGAGGATCGAGAAG & CAATGGCCACGTCATCTACG \\
\hline וג & GAGAGTGCAGCCCTAAGTGG & GGTTTACCCCTGAACGGTTT \\
\hline
\end{tabular}

Cad cadherin, ALP alkaline phosphatase, APN aminopeptidase N, Try trypsin, CYP cytochrome P450

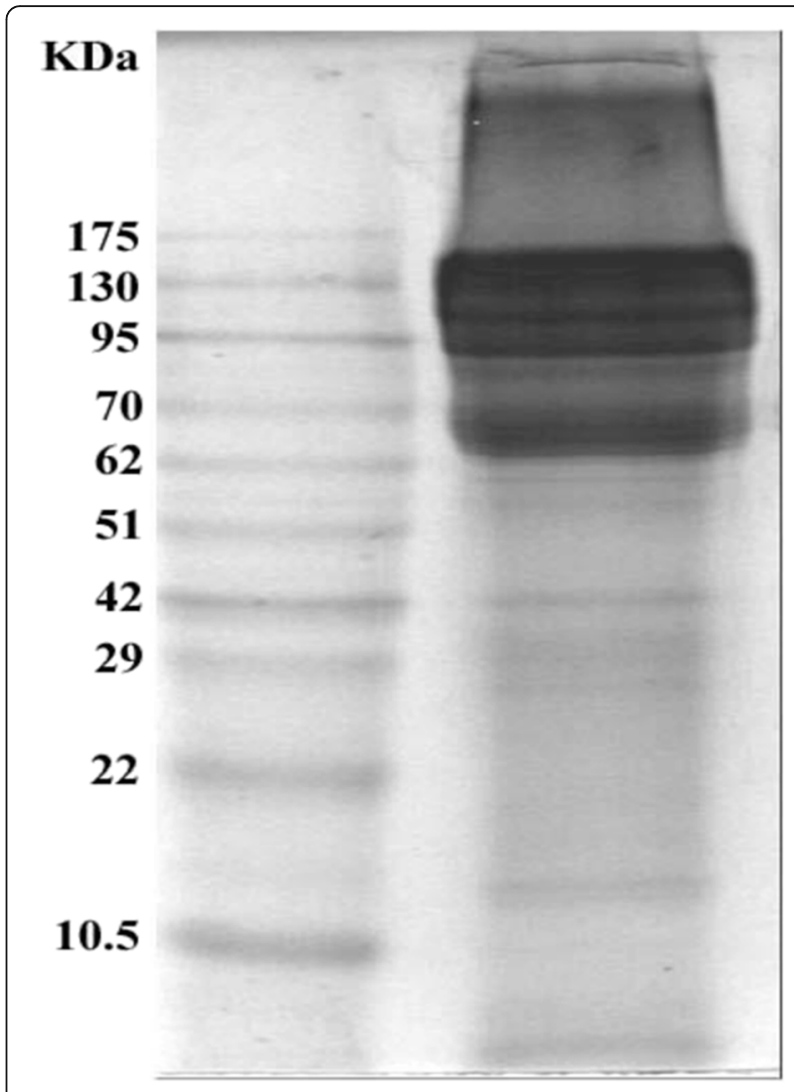

Fig. 1 10\% SDS-PAGE of Bt CrylC toxin

compared to $1.895 \mu \mathrm{g} / \mathrm{gm} \quad \mathrm{LC}_{50}$ of the susceptible strain. Therefore, the resistance ratio reached up to 6.5 -fold the susceptible strain (Table 4). The difference between the $\mathrm{LC}_{50}$ values of susceptible and tolerant strains was significant $(P<0.05)$, where the respective $95 \%$ fiducial limits were not overlapped.

\section{Histopathological studies}

Briefly, the midgut of the 3rd instar larvae of S. littoralis is made up of a single layer of epithelium resting on a basement membrane, surrounded by a layer of circular muscle fibers and an outer longitudinal muscle coat. The epithelium consists of 3 types of cells: columnar cells, goblet cells, and regenerative cells. The apical surface of each columnar cell bordering with the gut lumen is covered with microvilli. The gut lumen is lined with the peritrophic membrane (Fig. 2a). Light microscopy revealed that the midgut of late 3rd instar larvae of Cry $1 \mathrm{C}$-tolerant population of $S$. littoralis showed vacuolization of the epithelium and disruption of both the peritrophic membrane and the striated boarder (Fig. 2b). The lumen was collapsed and globular bodies and cytoplasmic fragments were observed pinching off from the tip of some of the epithelial cells within the 
Table 3 Mortality of susceptible and Bt Cry 1 C - tolerant strains of S. littoralis larvae

\begin{tabular}{lll}
\hline Strain & Toxin conc. $(\boldsymbol{\mu g} / \mathbf{g}$ diet $)$ & Mortality $(\%)$ \\
\hline Susceptible & 0.2 & 10.00 \\
& 0.4 & 16.67 \\
& 0.8 & 23.33 \\
& 1.6 & 40.00 \\
Tolerant 1st generation & 3.2 & 70.00 \\
& 0.5 & 6.67 \\
& 2.0 & 23.33 \\
Tolerant 10th generation & 6.0 & 60.00 \\
& 10.0 & 73.33 \\
& 4.0 & 6.67 \\
& 8.0 & 13.33 \\
& 16.0 & 33.33 \\
& 32.0 & 66.67 \\
\hline
\end{tabular}

lumen vicinal to the deteriorated peritrophic membrane.

\section{qPCR gene expression}

Understanding the mode of action of $B t$ toxins and the mechanism of tolerance is a critical point to identify the effective way to use these toxins in S. littoralis control. In order to investigate genes that might be involved in the insect's tolerance, a total RNAs were isolated from both susceptible and tolerant strains. The cDNAs were constructed, and qPCR was applied to assess the relative transcript abundance of cadherin (Cad), alkaline phosphatase (ALP), trypsin (Try), aminopeptidase N (APN), and cytochrome P450 (CYP) in susceptible and tolerant strains. The results reported here provided evidence about midgut receptors, proteases, and detoxification enzymes that associated with the processing of Bt Cry $1 \mathrm{C}$ toxin.

qPCR results showed about $(72 \%)$ reduction $(P<0.05)$ of Cad transcripts in tolerant strain than the susceptible one (Fig. 3). Abundance of ALP as a secondary receptor promoting the localization of toxin in the midgut was evaluated. Reduction of ALP transcripts in tolerant strain compared to susceptible strain was detected. In this study, APN transcript abundance did not differ significantly between susceptible and tolerant strains. About $49 \%$ reduction of Try transcripts in tolerant strain was revealed. Cytochrome P450 (CYP6AB14) was significantly over-transcribed in tolerant strain (Fig. 3 and Table 5).

\section{Discussion}

Bacillus thuringiensis (Bt), a soil bacterium, is the extreme successfully utilized biopesticide in agriculture. $B t$ contained insecticidal protein genes that are primary utilized for insect control in transgenic crops. Insect resistance to $B t$, it was a great challenge to sustainable success of the most extensively utilized transgenic crops (Tabashnik et al. 2013). There were many types of proteins that present in the midgut epithelial cells were either reported as transporters, which facilitate the toxicity functions or digestive proteases. For example, Cad (Walsh et al. 2018) and ALPs (Ren et al. 2018) that were shown to interact with Cry toxin(s) produced by different $B t$ strains and were described as Cry toxin functional receptors in midgut epithelium of insects. $B t$ was known to cause changes in the cell membrane, a common appearance of midgut degeneration (Cavados et al. 2004). In the present study, tolerant strain showed some disruptions in the gut lumen. However, of these disruptions, the gut functions were not affected and larvae can survive. This may indicated the regeneration of the tissues affected by Cry1C toxin. Forcada et al. (1999) proposed that enhanced gut healing response was a mechanism that involves $B t$ resistance. Castagnola and Jurat-Fuentes (2016) suggested that the increased production of new midgut growth factors cause an enhanced midgut regenerative response in resistant insects. This may be another way for the insect to tolerate $B t$ toxicity.

The results reported in the present study showed also the downregulation of cadherin (Cad) gene in tolerant strain than in the susceptible one. Downregulation of $\mathrm{Cad}$ and the subsequent reduction of $\mathrm{Bt} \mathrm{Cry} 1 \mathrm{C}$ binding and toxin oligomerization indicated the essential role of Cad gene in toxicity of Bt Cry $1 C$ toxin and tolerance selection. Recent studies have reported that at least two receptors on the insect midgut membrane interact with $B t$ toxins (Pigott and Ellar 2007). The midgut Cad (the first receptor) binds to activate $B t$ toxins with high affinity, and the interaction with Cad helped oligomerization of the toxins through a proteolytic process (Soberón et al. 2009). Therefore, the Cad gene low expression could lead to loose of oligomerization of the Bt Cry $1 C$ toxin, which in turn reflected the toxicity process. This result

Table 4 Susceptibility of susceptible and Bt Cry 1 C - tolerant strains (10th generation) of S. littoralis larvae

\begin{tabular}{lllll}
\hline Strain & LC $_{\mathbf{5 0}}(\mathbf{9 5} \% \mathrm{FL})(\boldsymbol{\mu g} / \mathbf{g}$ diet $)$ & Slope \pm SE & RR & $X_{(\mathbf{d f})}$ \\
\hline Susceptible & $1.8950(1.3193 .3-77)$ & $1.489249 \pm 0.290369$ & - & $1.761_{(3)}$ \\
Tolerant & $12.263(9.433-16.692)$ & $2.029307 \pm 0.311965$ & 6.5 & $1.212_{(3)}$ \\
\hline
\end{tabular}

95\% FL 95\% fiducial limits, SE standard error, $R R$ resistance ratio, $X^{2}$ chi-square, $d f$ degree of freedom 

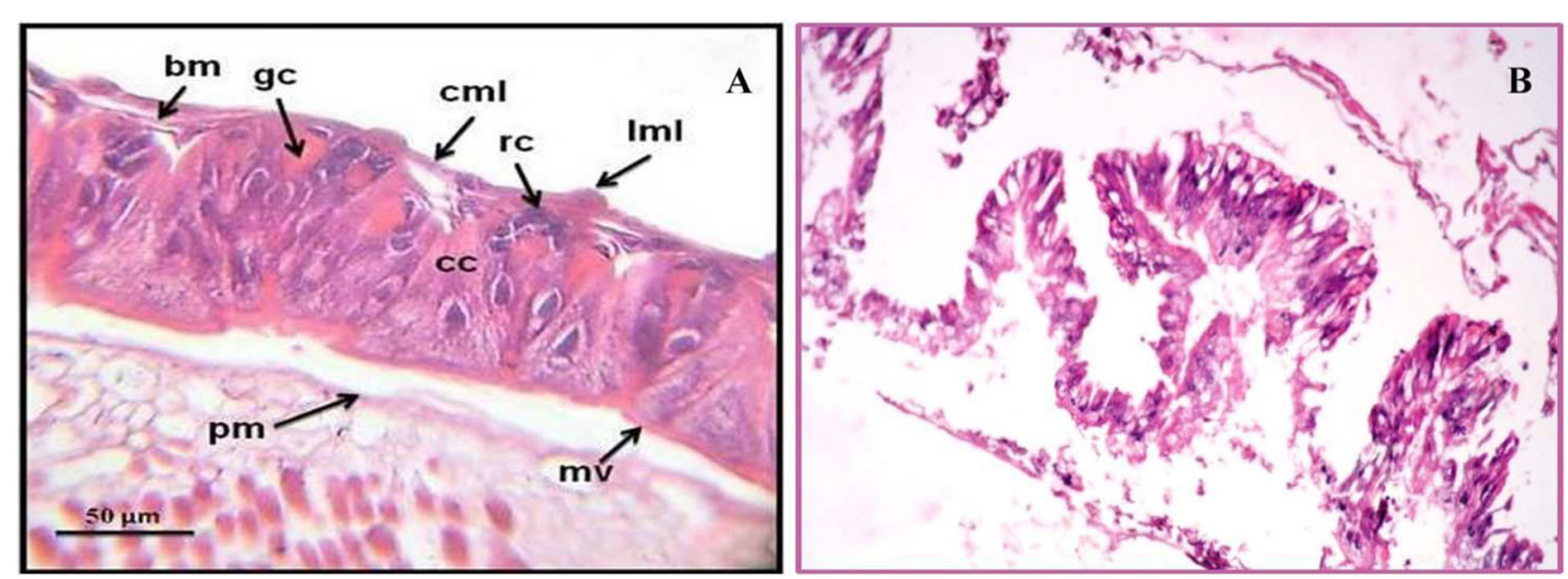

Fig. 2 Midgut of late third-instar larvae of Spodoptera littoralis $(\times 400)$. Susceptible strain (a), CrylC -tolerant strain (b). cc, columnar cell; mv, microvilli; rc, regenerative cell; cml, circular muscle layer; Iml, longitudinal muscle layer; gc, goblet cell; pm, peritrophic membrane

was consistent with earlier studies. For instances, downregulation of Cad has been reported in lepidopteran species including Helicoverpa armigera (Hübner) (Wang et al. 2005), Diatraea saccharalis (Fabricius) (Yang et al. 2011), Ostrinia furnacalis (Guenée) (Jin et al. 2014), Pectinophora gossypiella (Saunders) (Fabrick et al. 2019), and also in dipteran species as Aedes aegypti (Linnaeus) (Bonin et al. 2009). Literature proposed that downregulation of Cad was associated with Cry toxin resistance.
$\mathrm{Xu}$ et al. (2005) observed a completely disruption of the Cad gene by a premature stop codon in a Cry1Ac resistant strain of $H$. armigera. Jurat-Fuentes et al. (2004) also reported a retrotransposon-mediated disruption of the gene encoding Cad-like protein (HevCaLP) in a Cry1Ac-resistant strain of Heliothis virescens (Fabricius). Cad gene was suggested to be a biomarker for $B$. thuringiensis resistance screening in field populations of lepidopteran pests (Jurat-Fuentes et al. 2004). In

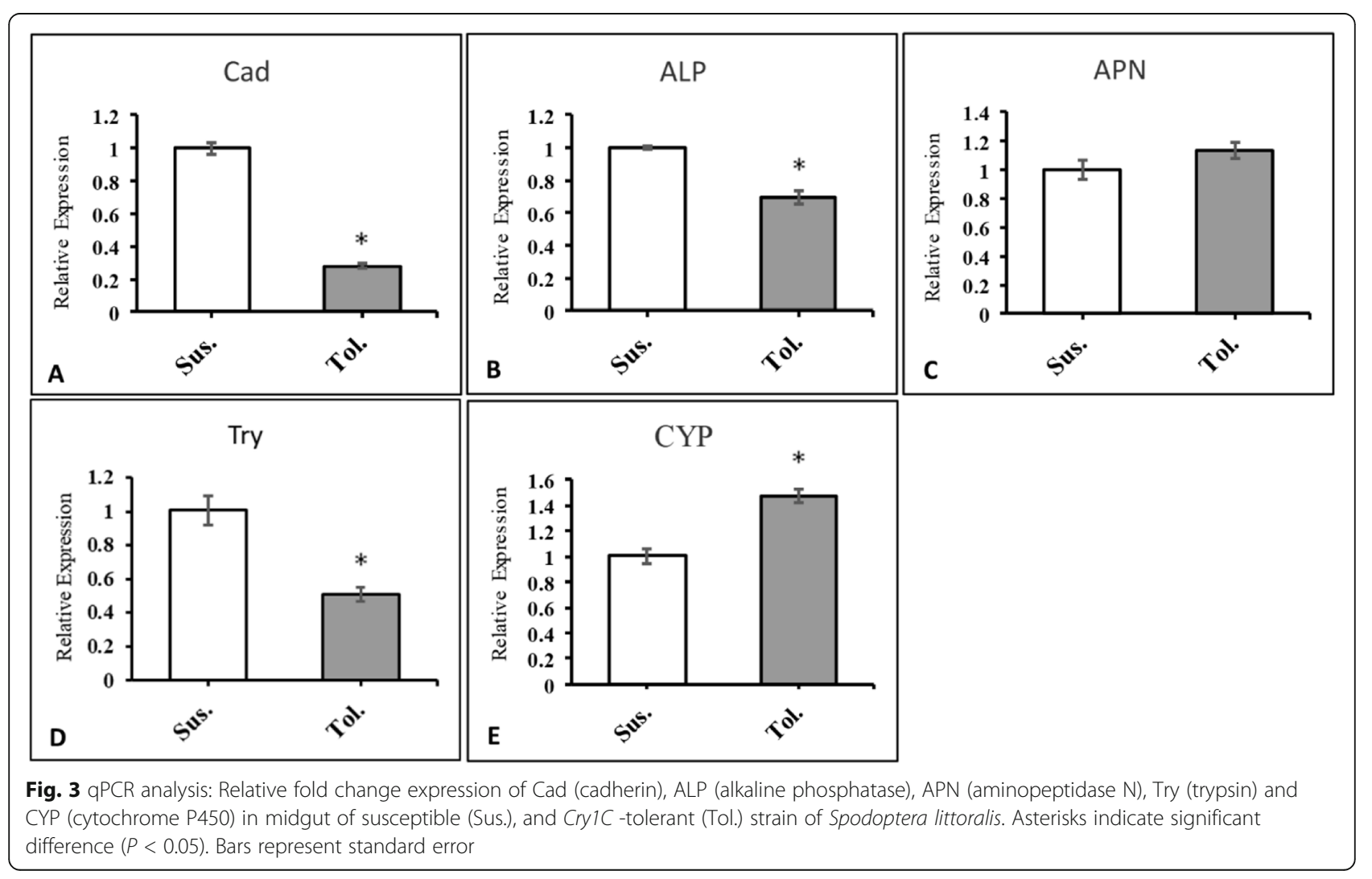


Table 5 qPCR analysis: Relative fold change expression of Cad (cadherin), ALP (alkaline phosphatase), APN (aminopeptidase N), Try (trypsin), and CYP (cytochrome P450) in midgut of susceptible (Sus.), and Bt Cry1C tolerant (Tol.) strain of S. littoralis

\begin{tabular}{|c|c|c|c|c|c|c|c|c|c|c|}
\hline & \multicolumn{2}{|l|}{ Cad } & \multicolumn{2}{|l|}{$A L P$} & \multicolumn{2}{|l|}{$A P N$} & \multicolumn{2}{|l|}{ Try } & \multicolumn{2}{|l|}{ CYP } \\
\hline & $\begin{array}{l}\Delta \mathrm{Ct} \text { of } \\
\text { Sus. }\end{array}$ & $\begin{array}{l}\Delta \mathrm{Ct} \text { of } \\
\text { Tol. }\end{array}$ & $\begin{array}{l}\Delta \mathrm{Ct} \text { of } \\
\text { Sus. }\end{array}$ & $\begin{array}{l}\Delta \mathrm{Ct} \text { of } \\
\text { Tol. }\end{array}$ & $\begin{array}{l}\Delta \mathrm{Ct} \text { of } \\
\text { Sus. }\end{array}$ & $\begin{array}{l}\Delta \mathrm{Ct} \text { of } \\
\text { Tol. }\end{array}$ & $\begin{array}{l}\Delta \mathrm{Ct} \text { of } \\
\text { Sus. }\end{array}$ & $\begin{array}{l}\Delta \mathrm{Ct} \text { of } \\
\text { Tol. }\end{array}$ & $\begin{array}{l}\mathrm{Ct} \text { of } \\
\text { Sus. }\end{array}$ & $\begin{array}{l}\Delta \mathrm{Ct} \text { of } \\
\text { Tol. }\end{array}$ \\
\hline Replica 1 & 12.57 & 14.45 & 5.64 & 6.25 & 6.46 & 6.15 & 1.24 & 1.85 & 10.76 & 10.25 \\
\hline Replica 2 & 12.5 & 14.29 & 5.6 & 5.99 & 6.15 & 6.29 & 0.85 & 2.26 & 10.94 & 10.29 \\
\hline Replica 3 & 12.4 & 14.23 & 5.67 & 6.23 & 6.4 & 6.03 & 1.19 & 2.13 & 10.64 & 10.13 \\
\hline Average $\Delta \mathrm{Ct}$ & 12.49 & 14.33 & 5.63 & 6.15 & 6.33 & 6.15 & 1.09 & 2.08 & 10.78 & 10.22 \\
\hline Fold of change $=2^{\Delta \Delta \mathrm{Ct}}$ & 1.00 & 0.28 & 1.00 & 0.69 & 1.00 & 1.13 & 1.00 & 0.51 & 1.00 & 1.47 \\
\hline$\%$ of gene transcripts & \multicolumn{2}{|c|}{$72 \%$ downregulation } & \multicolumn{2}{|c|}{$31 \%$ downregulation } & \multicolumn{2}{|c|}{$\begin{array}{l}13 \% \text { not differ } \\
\text { significantly }\end{array}$} & \multicolumn{2}{|c|}{ 49\% downregulation } & \multicolumn{2}{|c|}{$\begin{array}{l}47 \% \text { significantly } \\
\text { over-transcribed }\end{array}$} \\
\hline
\end{tabular}

addition, the results showed that aminopeptidase $\mathrm{N}$ (APN) transcript abundance did not differ significantly between susceptible and tolerant strains. This may refer that APN did not associate with $B t C r y 1 C$ tolerance in $S$. littoralis. In contrast, previous studies showed that alterations in expression of APN have been associated with $B t$ resistance in several species of insect pests (Zhang et al. 2017). The $B t$ oligomers had a high binding affinity to APN or alkaline phosphatase (ALP) (a secondary receptor), which finally led to oligomers insertion into the midgut cell membrane, with resulting cell lysis. It also has been proposed that binding of $B t$ toxins to the Cad may activate a cellular signaling pathway leading to cell death without the involvement of APN (Zhang et al. 2006). This may explain obtained results and supports the unchanged expression level of APN between the two strains. Thus, APN might not be a core receptor for $B t$ Cry1C in S. littoralis and did not involve in toxicity. Further experiments are needed to test this hypothesis.

In the $B t C r y 1 C$-tolerant strain, ALP expression level was significantly reduced than the susceptible one. This lack of expression showed the crucial role of ALP in toxin insertion through the midgut and pore formation. The role of ALP in the susceptibility of insects to Cry toxins has been demonstrated in several studies (JuratFuentes and Adang, 2004 and Qiu et al. 2018). Knockdown of ALP gene in the rice borer, Chilo suppressalis, exhibited decreased susceptibility to transgenic Cry1A rice (Qiu et al. 2018). Also, other transcripts, which were downregulated in this study in the tolerant strain that was previously documented as remarkable $B t$ genes/proteins involved in insecticide resistance in many insects, which is trypsin-like serine protease. Thus, downregulation of trypsin will be resulted in improper and insufficient activation of $B t C r y 1 C$ protoxin, which may be a key factor in tolerance development. Cis-mutations identified in the promoter region of a trypsin gene conferred high resistance to Cry1Ac in $H$. armigera (Liu et al. 2014). However, the most reports indicated that variations in toxin activation were commonly not a main mechanism of resistance to $B t$ proteins (Wei et al. 2016). Cytochrome P450 (CYP6AB14) was significantly overtranscribed in the present investigation. This induction may reveal the relation between detoxification activity and tolerance. Expression and activity of P450 enzyme was different through resistant insect populations, some studies reported upregulation and others reported downregulation (Vellichirammal et al. 2015). In previous studies, P450 gene was reported to confer resistance and was involved in detoxifications of xenobiotics (Pavlidi et al. 2018), as well as trypsin, which is considered the essential protein involved in $B t$ toxin activation and detoxification (Liu et al. 2014). Therefore, further studies are needed to be conducted to identify the major and precise role of cytochrome P450 in detoxification and tolerance of $B t$.

\section{Conclusion}

The present study concluded that toxin activation, binding, and detoxification were critical procedures of $B t$ Cry1C toxification in S. littoralis. Trypsin, aminopeptidase $\mathrm{N}$, alkaline phosphatase, cadherin, and cytochrome P450 are among different proteins that involved in Bt resistance and toxicity. Further studies are required to better understand how these proteins are regulated and their role in $B t$ tolerance.

\footnotetext{
Abbreviations

S. littoralis: Spodoptera littoralis; Bt: Bacillus thuringiensis; Try: Trypsin; APN: Aminopeptidase N; ALP: Alkaline phosphatase; Cad: Cadherin; CYP: Cytochrome P450; cDNAs: Complementary deoxyribonucleic acids; qPCR: Quantitative real-time polymerase chain reaction; BBMVs: Brush border membrane vesicles; EDTA: Ethylenediaminetetraacetic acid; SDS

PAGE: Sodium dodecyl sulfate-polyacrylamide gel electrophoresis; DTT: Dithiothreitol; LC 50 : Lethal concentration; RR: Resistance ratio; cat \#: Catalog number; MultAlin: Multiple alignment; $\Delta$ : Delta; $\leq$ : Less than or equal; 135 kDa: About 135 kilo Dalton; PCR: Polymerase chain reaction; MSA: Multiple sequence alignment
} 


\section{Authors' contributions}

$\mathrm{NIE}, \mathrm{HSZ}$, and SM conceived and designed the study; HK, NIE, DSA, HSZ, EHS, and SM performed experiments, drafted, and edited the manuscript. All authors read and approved the final manuscript.

\section{Funding}

Not applicable.

\section{Availability of data and materials}

All data of the study have been presented in the manuscript, and high quality and grade materials were used in this study.

\section{Ethics approval and consent to participate}

Not applicable.

\section{Consent for publication}

Not applicable.

\section{Competing interests}

The authors declare no competing interests.

\section{Author details}

'Plant Protection Research Institute (PPRI), Agricultural Research Center, Giza, Egypt. ${ }^{2}$ Genetics Department, Faculty of Agriculture, Cairo University, Giza 12613, Egypt. ${ }^{3}$ Entomology Department, Faculty of Science, Cairo University, Giza 12613, Egypt.

Received: 11 September 2020 Accepted: 28 January 2021

\section{Published online: 09 February 2021}

\section{References}

Abbott WS (1925) A method of computing the effectiveness of an insecticide. J Econ Entomol 18:265-267

Abdelhadi AA, Elarabi NI, Salim RG, Sharaf AN, Abosereh NA (2016) Identification, characterization and genetic improvement of bacteriocin producing lactic acid bacteria. Biotechnology 15(3-4):76-85. https://doi.org/10.3923/biotech. 2016.76 .85

Bancroft JD, Gamble M (2008) Theory and practice of histological techniques, 6th edn. Churchill Livingstone, Elsevier, China

Bonin A, Paris M, Tetreau G, David JP, Després L (2009) Candidate genes revealed by a genome scan for mosquito resistance to a bacterial insecticide: sequence and gene expression variations. BMC Genomics 10:551. https://doi. org/10.1186/1471-2164-10-551

Boyer S, Paris M, Jego S, Lempérière G, Ravanel P (2012) Influence of insecticide Bacillus thuringiensis subsp. israelensis treatments on resistance and enzyme activities in Aedes rusticus larvae (Diptera: Culicidae). Biol Control 62:75-81. https://doi.org/10.1016/j.biocontrol.2012.02.001

Bradford MM (1976) A rapid and sensitive method for the quantitation of microgram quantities of protein utilizing the principle of protein-dye binding. Anal Biochem 72:248-254. https://doi.org/10.1016/00032697(76)90527-3

Castagnola A, Jurat-fuentes JL (2016) Intestinal regeneration as an insect resistance mechanism to entomopathogenic bacteria. Curr Opin Insect Sci 15:104-110. https://doi.org/10.1016/j.cois.2016.04.008

Cavados C, Majerowicz S, Chaves J, Araújo-coutinho C, Rabinovitch L (2004) Histopathological and ultrastructural effects of delta-endotoxins of Bacillus thuringiensis Serovar israelensis in the Midgut of Simulium pertinax Larvae (Diptera, Simuliidae). Mem Inst Oswaldo Cruz 99:493-498. https://doi.org/10. 1590/S0074-02762004000500006

Corpet F (1988) Multiple sequence alignment with hierarchical clustering. Nucleic Acids Res 16:10881-10890

Dhania NK, Chauhan VK, Chaitanya RK, Dutta-gupta A (2019) Midgut de novo transcriptome analysis and gene expression profiling of Achaea janata larvae exposed with Bacillus thuringiensis (Bt)-based biopesticide formulation. Comp Biochem Physiol Part D 30:81-90. https://doi.org/10.1016/j.cbd.2019.02.005

Dingha BN, Moar WJ, Appel AG (2004) Effects of Bacillus thuringiensis Cry1C toxin on the metabolic rate of $B t C r y 1 C$ resistant and susceptible Spodoptera exigua (Lepidoptera: Noctuidae). Physiol Entomol 29:409-418. https://doi.org/10. 1111/j.0307-6962.2004.00409.x

El-defrawi M, Toppozada A, Mansour N, Zeid M (1964) Toxicological studies on the Egyptian cotton leaf worm, Prodenia litura. I. Susceptibility of Different
Larval Instars of Prodenia to Insecticides. J Econ Entomol 57:591-593. https:// doi.org/10.1093/jee/57.4.591

Fabrick JA, Mathew LG, Leroy DM, Hull JJ, Unnithan GC, Yelich AJ, Carrière Y, Li X, Tabashnik BE (2019) Reduced cadherin expression associated with resistance to Bt toxin Cry1Acin pink bollworm. Pest Manag Sci 76:67-74. https://doi.org/ 10.1002/ps.5496

Forcada C, Alcácer E, Garcerá MD, Tato A, Martínez R (1999) Resistance to Bacillus thuringiensis Cry $1 \mathrm{Ac}$ toxin in three strains of Heliothis virescens: proteolytic and SEM study of the larval midgut. Arch Insect Biochem Physiol 42:51-63 https://doi.org/10.1002/(SICI)1520-6327(199909)42:1<51::AID-ARCH6>3.0.CO;26

ISAAA (2017) Global status of commercialized biotech/GM crops in 2017: biotech crop adoption surges as economic benefits accumulate in 22 years. ISAAA Briefs ISAAA, Ithaca, NY

James C (2009) Brief 41: Global status of commercialized biotech/GM crops: 2009 ISAAA Brief, Ithaca, NY

Jin L, Wang J, Guan F, Zhang J, Yu S, Liu S, Xue Y, Li L, Wu S, Wang X, Yang Y, Abdelgaffar H, Jurat-fuentes JL, Tabashnik BE, Wu Y (2018) Dominant point mutation in a tetraspanin gene associated with field-evolved resistance of cotton bollworm to transgenic Bt cotton. Proc Natl Acad Sci 115:1176011765. https://doi.org/10.1073/pnas.1812138115

Jin T, Chang X, Gatehouse AMR, Wang Z, Edwards MG, He K (2014) Down regulation and mutation of a cadherin gene associated with Cry $1 \mathrm{Ac}$ resistance in the Asian corn borer, Ostrinia furnacalis (Guenée). Toxins 6: 2676-2693. https://doi.org/10.3390/toxins6092676

Jurat-fuentes JL, Gahan LJ, Gould FL, Heckel DG, Adang MJ (2004) The HevCaLP protein mediates binding specificity of the Cry1A class of Bacillus thuringiensis toxins in Heliothis virescens. Biochemistry 43:14299-14305. https://doi.org/10.1021/bi048500i

Liu C, Xiao Y, Li X, Oppert B, Tabashnik BE, Wu K (2014) Cis-mediated downregulation of a trypsin gene associated with $\mathrm{Bt}$ resistance in cotton bollworm. Sci Rep 4:7219. https://doi.org/10.1038/srep07219

Livak KJ, Schmittgen TD (2001) Analysis of relative gene expression data using real-time quantitative PCR and the $2^{-\Delta \Delta C T}$ method. Methods 25:402-408. https://doi.org/10.1006/meth.2001.1262

Moussa S, Biaomy F, Aiad K, Khalil H, Abd El-latif AO (2020) Bacillus thuringiensis Cry $1 \mathrm{C}$ resistance development and its processing pattern in Egyptian cotton leaf worm: Spodoptera littoralis (Boisd.) (Lepidoptera: Noctuidae). Egypt J Biol Pest Control 30(1):1-5. https://doi.org/10.1186/s41938-020-00237-w

Moussa S, Kamel E, Ismail IM, Mohammed A (2016) Inheritance of Bacillus thuringiensis Cry $1 \mathrm{C}$ resistance in Egyptian cotton leafworm, Spodoptera littoralis (Lepidoptera: Noctuidae). Entomol Res 46:61-69. https://doi.org/10. 1111/1748-5967.12148

Pardo-lópez L, Soberón M, Bravo A (2013) Bacillus thuringiensis insecticidal threedomain Cry toxins: mode of action, insect resistance and consequences for crop protection. FEMS Microbiol Rev 37:3-22. https://doi.org/10.1111/j.1574$6976.2012 .00341 . x$

Pavlidi N, Vontas J, Van LT (2018) The role of glutathione S-transferases (GSTs) in insecticide resistance in crop pests and disease vectors. Curr Opin Insect Sci 27:97-102. https://doi.org/10.1016/j.cois.2018.04.007

Pigott CR, Ellar DJ (2007) Role of receptors in Bacillus thuringiensis crystal toxin activity. Microbiol Mol Biol Rev 71:255-281. https://doi.org/10.1128/MMBR. 00034-06

Qiu L, Wang P, Wu T, Li B, Wang X, Lei C, Lin Y, Zhao J, Ma W (2018) Down regulation of Chilo suppressalis alkaline phosphatase genes associated with resistance to three transgenic Bacillus thuringiensis rice lines. Insect Mol Biol 27:83-89. https://doi.org/10.1111/imb.12349

Rajagopal R, Arora N, Sivakumar S, Rao NGV, Nimbalkar SA, Bhatnagar RK (2009) Resistance of Helicoverpa armigera to Cry1Ac toxin from Bacillus thuringiensis is due to improper processing of the protoxin. Biochem J 419:309-316. https://doi.org/10.1042/BJ20081152

Ren XL, Hu HY, Jiang WL, Ma XY, Ma YJ, Li GQ, Ma Y (2018) Three GPI anchored alkaline phosphatases are involved in the intoxication of $\mathrm{Cry} 1 \mathrm{Ca}$ a toxin to Spodoptera exigua larvae. J Invertebr Pathol 151:32-40. https://doi.org/10. 1016/j.jip.2017.10.009

Shabbir MZ, Zhang T, Wang Z, He K (2019) Transcriptome and proteome alternation with resistance to Bacillus thuringiensis Cry1Ah toxin in Ostrinia furnacalis. Front Physiol 10:27. https://doi.org/10.3389/fphys.2019.00027

Soberón M, Gill SS, Bravo A (2009) Signaling versus punching hole: how do Bacillus thuringiensis toxins kill insect midgut cells? Cell Mol Life Sci 66:13371349. https://doi.org/10.1007/s00018-008-8330-9 
Soberón M, Monnerat R, Bravo A (2018) Mode of action of Cry toxins from Bacillus thuringiensis and resistance mechanisms. In: Gopalakrishnakone P, Stiles B, Alape-girón A, Dubreuil JD, Mandal M (eds.) Microbial Toxins. 1 ed Springer Netherlands.

Tabashnik BE, Bre'vault T, Carrie’re Y (2013) Insect resistance to Bt crops: lessons from the Prst billion acres. Nat Biotechnol 31:510-521. https://doi.org/10. 1038/nbt.2597

van Lenteren JC, Bolckmans K, Köhl J, Ravensberg WJ, Urbaneja A (2018) Biological control using invertebrates and microorganisms: plenty of new opportunities. BioControl. 63(1):39-59. https://doi.org/10.1007/s10526-0179801-4

Vellichirammal NN, Wang H, Eyun Sl, Moriyama EN, Coates BS, Miller NJ, Siegfried BD (2015) Transcriptional analysis of susceptible and resistant European corn borer strains and their response to Cry1F protoxin. BMC Genomics 16:558. https://doi.org/10.1186/s12864-015-1751-6

Walsh J, Clucas G, MacManes M, Thomas K, Kovach A (2018) Divergent selection and drift shape the genomes of two avian sister species spanning a salinefreshwater ecotone. bioRxiv. https://doi.org/10.1101/344614

Wang G, Wu K, Liang G, Guo Y (2005) Gene cloning and expression of cadherin in midgut of Helicoverpa armigera and its Cry1 A binding region. Sci China C Life Sci 48:346-356. https://doi.org/10.1360/03yc0273

Wei J, Liang G, Wang B, Zhong F, Chen L, Khaing MM, Zhang J, Guo Y, Wu K, Tabashnik BE (2016) Activation of Bt protoxin Cry1Ac in resistant and susceptible cotton bollworm. PLoS One 11:e0156560. https://doi.org/10.1371/ journal.pone.0156560

Xiao Y, Wu K (2019) Recent progress on the interaction between insects and Bacillus thuringiensis crops. Philos Trans R Soc B 374:20180316. https://doi. org/10.1098/rstb.2018.0316

Xu X, Yu L, Wu Y (2005) Disruption of a cadherin gene associated with resistance to Cry1Ac $\delta$-endotoxin of Bacillus thuringiensis in Helicoverpa armigera. Appl Environ Microbiol 71:948-954. https://doi.org/10.1128/AEM.71.2.948-954.2005

Yang Y, Zhu YC, Ottea J, Husseneder C, Leonard BR, Abel C, Luttrell R, Huang F (2011) Down regulation of a gene for cadherin, but not alkaline phosphatase, associated with Cry $1 \mathrm{Ab}$ resistance in the sugarcane borer Diatraea saccharalis. PLoS One 6. https://doi.org/10.1371/journal.pone.0025783

Zhang T, Coates BS, Wang Y, Wang Y, Bai S, Wang Z, He K (2017) Downregulation of aminopeptidase $\mathrm{N}$ and $\mathrm{ABC}$ transporter subfamily $\mathrm{G}$ transcripts in Cry $1 \mathrm{Ab}$ and Cry $1 \mathrm{Ac}$ resistant Asian corn borer, Ostrinia furnacalis (Lepidoptera: Crambidae). Int J Biol Sci 13:835-851. https://doi.org/10.7150/ ijbs. 18868

Zhang X, Candas M, Griko NB, Taussig R, Bulla LA (2006) A mechanism of cell death involving an adenylyl cyclase/PKA signaling pathway is induced by the Cry1Ab toxin of Bacillus thuringiensis. Proc Natl Acad Sci 103(26):9897-9902 https://doi.org/.1073/pnas.0604017103

\section{Publisher's Note}

Springer Nature remains neutral with regard to jurisdictional claims in published maps and institutional affiliations.

\section{Submit your manuscript to a SpringerOpen ${ }^{\circ}$ journal and benefit from:}

- Convenient online submission

- Rigorous peer review

- Open access: articles freely available online

- High visibility within the field

- Retaining the copyright to your article

Submit your next manuscript at $\boldsymbol{\nabla}$ springeropen.com 